\title{
The analysis of land use weights on road traces selection
}

\author{
Indrayani ${ }^{1,2, *}$, Erika Buchari ${ }^{3}$, Dinar D. A. Putranto ${ }^{3}$, and Edward $\mathrm{Saleh}^{4}$ \\ ${ }^{1}$ Doctoral Student of Environmental Science of Sriwijaya University, Palembang, Indonesia \\ ${ }^{2}$ Civil Engineering Department, State Polytechnic of Sriwijaya, Palembang, Indonesia \\ ${ }^{3}$ Civil Engineering Department, Faculty of Engineering, Sriwijaya University, Palembang, Indonesia \\ ${ }^{4}$ Faculty of Agriculture, Sriwijaya University, Palembang, Indonesia
}

\begin{abstract}
Land use is a basic factor in determining road traces for residential, industrial or other space areas. The existence of spatial layout will affect the class of road, where the construction of new roads should not spoil the existing spatial layout. In swamp areas, land use is more dominated by agriculture, plantations, and forests such as the presence of swamp areas in Banyuasin District [1][2][13]. The development of swamp areas that are currently being upgraded requires road infrastructure, so it is necessary to undertake a study of the selection of road traces based on existing land use, then in order to gain priority of the land use based on the importance level on the selection of road traces opinion from stakeholders is required, so the selection of road traces in swamp areas can be more economical. Data collection was done through questionnaires distributed to respondents from stakeholders related to road and environmental fields, then analysis of the importance level was done using AHP method. From the analysis results the weights of the importance of land use for the selection road traces was obtained, which are namely shrub/bushes (29.99\%), plantation $(22.79 \%)$, rice field $(19,74 \%)$, settlements $(10.48 \%)$, forest $(9.77 \%)$, water body $(7.22 \%)$.
\end{abstract}

\section{Introduction}

Land use and economic growth factors are among the factors that must be considered in determining road traces [3]. Land use is a pattern of area use associated with human activities [4]. This is also related to the determination of the road class that depends on the spatial layout of the road, therefore the existence of a new road should not spoil the existing spatial layout. We recommend that the existence of the road should be able to increase the harmony of the use of existing space, but if the land does not have a spatial, then it makes the road as a means to form the orientation of spatial and the existence of the road as a corridor of space [3].

Land use will automatically include the concept of optimization, evaluation, and land planning. So far, the development and changing patterns of land use developed dynamically for nature are influenced by several factors, namely the first is the human factor that

* Corresponding author: iiend.indrayani@gmail.com 
includes the needs of shelter, socio-cultural, financial, and technology; the second is the physical factor whereby the city is the center of growth and transport network in accessibility and the third is the landscape factor which is the slope and the land elevation [5]. While other opinions state that land use is a human effort in utilizing its natural environment to meet the needs of life and the relationship of human interaction with the environment, where the focus of the environment is the land, while the attitude and response of human policies on the land can determine the steps of its activities [6]. The factors contributing to land use include the expansion of city limits, the expansion of infrastructure networks, the rejuvenation of urban centers, as well as the growth of centralized activities. Changes in land cover have a very significant impact on climate, hydrology, water sources, soils, and biota [7]. Meanwhile, in natural conditions before it is opened, swamps are covered with a variety of aquatic plants, shrub or forest vegetation, the soil is water-saturated or has shallow groundwater or is inundated [8]. While in some swampy areas land use is dominated by agriculture, plantations, and forests such as swamp areas in Banyuasin Regency [1] [2] [13]. At this time development in the swamp area is more massively done considering the land in the increasingly limited productive areas and the government continues to develop swamp areas both in the agricultural sector, plantations, and fisheries [9], so to support the development in this swamp area of course road infrastructure is needed. Meanwhile, roads built should pay attention to economic factors and environmental conditions to achieve sustainable development, therefore it is necessary to analyze land use in selection traces of roads, especially in swamp areas.

\section{Research methodology}

The goal of this study is to obtain the weight of land use from stakeholders in the selection of road traces especially in swamp areas, where the classification of land use taken is based on previous research results that divide land use in swamp areas into 6 classes, namely forest, plantation, rice field, shrubs/ bushes, settlements, and water body [1] [2] [13]. This research is a follow-up study to find the suitability of road trace in swamp area which has been done by previous researcher so that the land use used refers to the result of the research. Meanwhile, the stakeholders who are respondents in this research are people related to the road and environmental field, against the background of the Department of Public Works and Highway, the Department of Environment/environmental consultants that consisting of Head of Department, Head of Division/Section and Head of Sub-Section of each agency, while from the college background there are lecturers with doctorates and professors who are masters at road and environmental issues. To support accurate results, the questionnaires were distributed in two provinces, namely South Sumatra and West Kalimantan, as these two provinces have the largest swamp areas in Indonesia.

The data collection was done by distributing questionnaires to the respondents with the question: "based on your opinion which area is best suited to be chosen as road traces in the swamp area", where level of conformity of land use is assessed based on a scale of 1 to 9 , namely: 3 relatively important, 5 more important, 7 is very important, and 9 is much more important. While the importance level 2,4,6,8 are inter values. Furthermore, the answers obtained are analyzed using the AHP method for the priority level of the importance of land use in the selection of road traces in the swamp area, then each assessment of the respondents will be tested for consistency because in the AHP method logical consistency indicates consistency or lack of assessment. While the consistency ratio can be calculated by the equation:

$$
C R=C I / R I
$$


The equation to get the consistency index is:

$$
C I=(\lambda \max -n) /(n-1)
$$

where: $\lambda \max =$ the largest eigenvector value of the comparison matrix; $\mathrm{n}=$ matrix size.

If the $\mathrm{CR}$ value is greater than $10 \%$ then the pairwise comparison must be repeated. The value of the Random Index (RI), which is equal to (RI / order matrix) is (1/0); (2/0); $(3 / 0,58)$; $(4 / 0,9)$; $(5 / 1,12) ;(6 / 1,24) ;(7 / 1,32) ;(8 / 1,41) ;(9 / 1,45) ;(10 / 1,49)$ (Saaty, 2008).

To be able to know the tendency of assessment of the respondents based on the background of work, the initial weighting assessment will be separated against each background, furthermore a combined weighting will be done, and that will be the basis for the selection of road traces on the swamp areas based on land use.

\section{Result}

To be able to see the weighting level of each respondent field, the weighting assessment is reviewed in 3 groups and then the combined weighting to get the weights rating from the land use in the road traces selection is done, especially in the swamp area. Consistency of the land use weights ratio of the data results is $0.097<0.10$, this indicates that the weights of land use from the stakeholder assessment can be used in determining the suitability of the road traces

The weighting result of the level of importance Department of Public Works and Highway background can be seen in Fig. 1 .

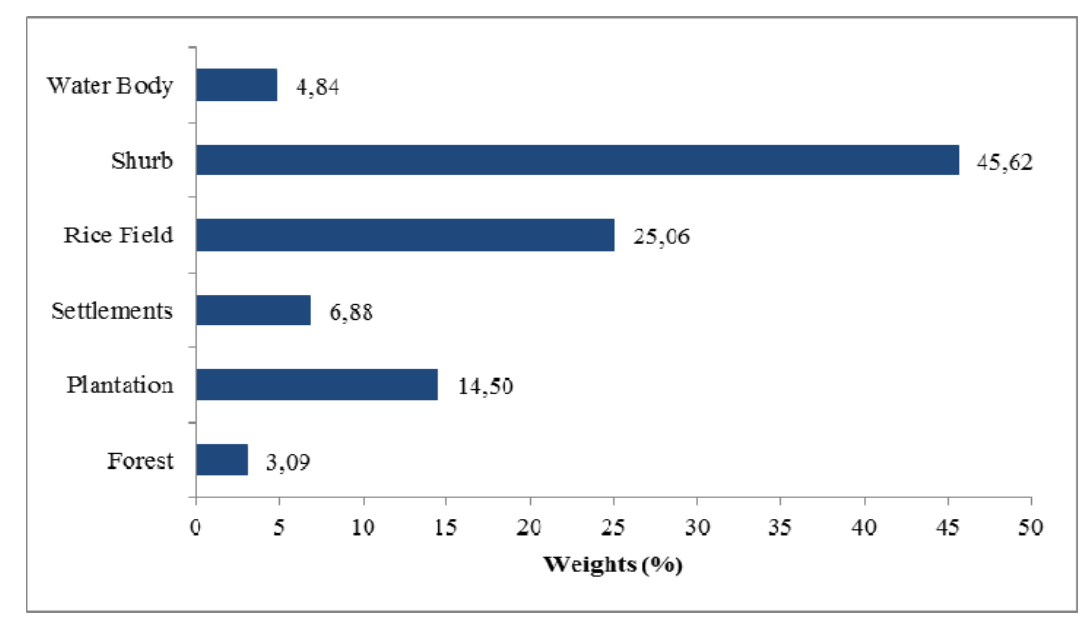

Fig. 1. The weighting of land use from the Department of Public Works and Highway background.

Fig. 1 shows the highest to the lowest order of weights to consider in determining the road traces is the shrub/bushes, plantation, rice field, settlements, forest, and water body. From this result, it can be seen that stakeholders of the Department of Public Works and Highway would prioritize the shrub/bushes for the road traces selection, this is due to economic considerations that land acquisition in bush/shrub areas will be cheaper so that it is more efficient, as well as on the sequence of other land uses, this consideration is more on the cost of more economical land acquisition.

The weighting results of the importance level from the Department of Environment/ environmental consultants background can be seen in Fig. 2. 


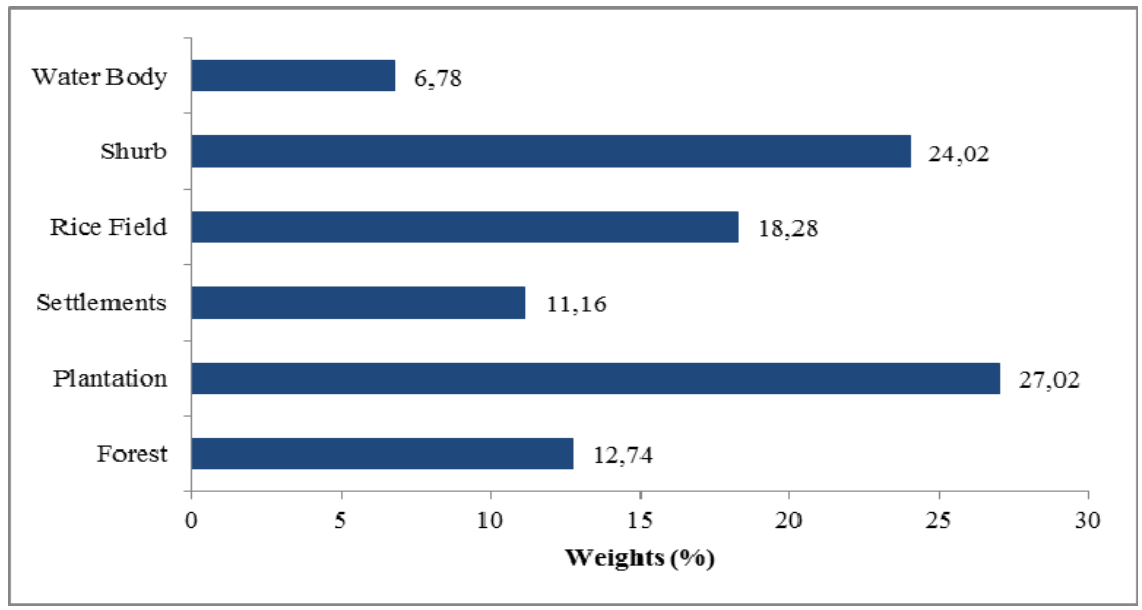

Fig. 2. The weighting of land use from the Department of Environment/environmental consultants.

Fig. 2 shows the highest to the lowest order of weights to consider in determining the road traces is the plantation, shrub/bushes, rice field, settlements, forest, and water body. From these results, it can be seen that the stakeholders of the Environmental Department / environmental consultant, will prioritize plantations in the selection of road traces, considering that the plantation area is the dominant area in the swamp area, so that road infrastructure is needed to support the marketing of the products, this is closely related to the socio-economic factors of a region.

The weighting results of the importance level from academic's background can be seen in Fig. 3.

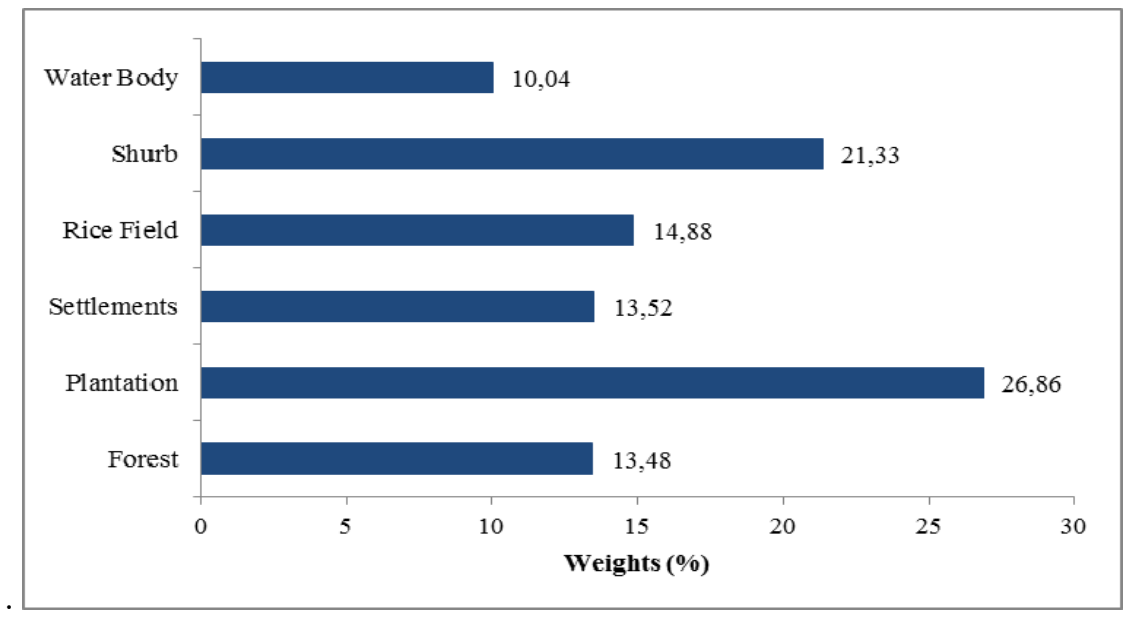

Fig. 3. The weighting of land use from the college background.

Fig. 3 shows the highest to the lowest order of weights to consider in determining the road traces is plantation, shrub/bushes, rice field, settlements, forest, and water body, when this is viewed in the order of land use priorities are similar to stakeholder assessments from the Department of Environment/environmental consultants background.

The weighting and ranking of land use assessment results can be seen in Table 1. Whereas, the combined weighting results can be seen in Fig. 4. 
Table 1. The weighting and ranking of land use assessment.

\begin{tabular}{|c|c|c|c|}
\hline No & Criteria & Weights (\%) & Rank \\
\hline 1 & Forest & 9.77 & 5 \\
\hline 2 & Plantation & 22.79 & 2 \\
\hline 3 & Settlements & 10.48 & 4 \\
\hline 4 & Rice Field & 19.74 & 3 \\
\hline 5 & Shrub/Bushes & 29.99 & 1 \\
\hline 6 & Water Body & 7.22 & 6 \\
\hline
\end{tabular}

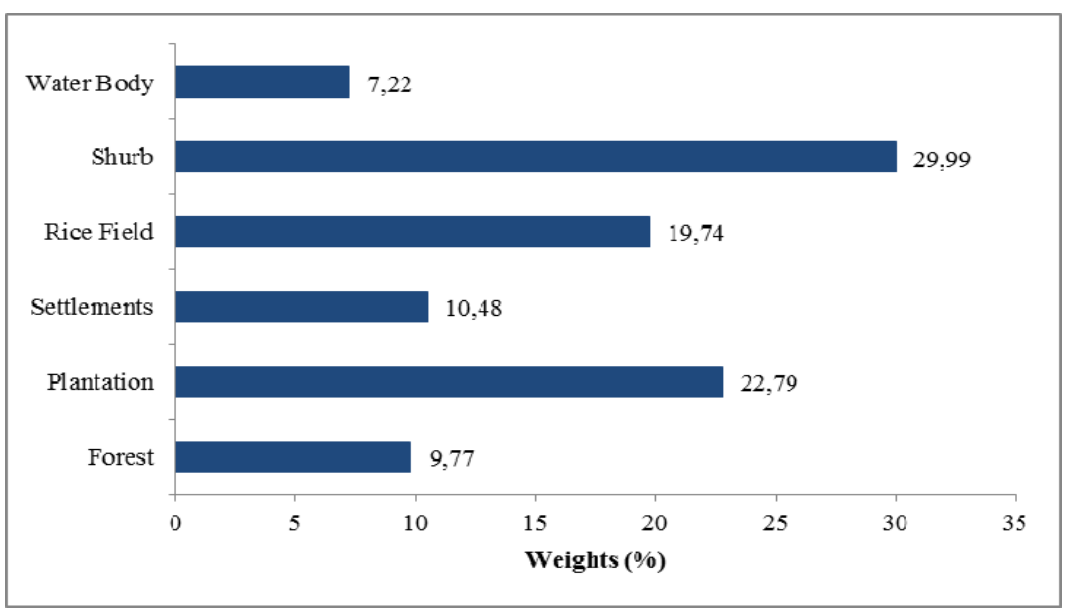

Fig. 4. The combined weighting results.

The results of the combined assessment obtained shows the highest to the lowest order of weights to consider in determining the road traces in swamp area shrub/bushes, plantation, rice field, settlements, forest and water body.

\section{Discussion}

From the analysis result, those that have the rank of conformity priority of road trace selection based on land use were shrubs/bushes, plantation, rice field, settlements, forest, and water body (river). If evaluated from the prevailing regulations on the determination of the road traces, then the road built should pay attention to land use, where the focus of the selection of land use is the cost of land acquisition, while the other factor is the socioeconomic environment factor [15]. This is in line with the results of the assessment of the stakeholders that the first order in the selection of road trails is shrubbery, because land acquisition will be cheaper when compared with other areas. While on the second rank is plantation, this will be related to the socio-economic condition because with the road passing through plantations, the accessibility will be smoother, likewise on the third order, the rice field, because the rice field is also related to the socio-economic condition [15]. In the fourth settlement area land acquisition must consider many aspects. Water bodies (rivers) are ranked fifth because the costs incurred could be larger due to the fact that it has to consider the cost of bridge construction, in addition, the pattern of settlements in the swamp or lowland areas tend to follow the pattern of the river's flow [11][12] so that they 
utilize river transportation more in doing their activities. While the final sequence in the selection of road trails is forest areas, this is certainly related to the law of "protection of forest areas" [14], so the selection of road traces should avoid forest areas. The settlement is the fourth place in the consideration of the road traces selection because land acquisition in residential areas should consider many aspects, where land acquisition on road construction is not as simple as land acquisition for other activities, where the land acquisition will vary depending on the location of the road built. While in the fifth place in the selection of the road lane is the forest area, this is, of course, related to environmental issues since there is a "forest area protection" ordinance which prohibits the construction of roads in protected forest areas [14], so the road trail selection should avoid forest areas. And in the last order is the water body (river) with consideration that the costs incurred can be larger because it should consider the cost of the construction of the bridge, other than that, the pattern of settlements in the swamp or lowlands tend to follow the pattern of the river's flow [11][12] so that they utilize river transportation more in their activities.

\section{Conclusion}

The order of importance of land use is based on weights value in the selection traces of the road in swamp areas, which is namely: shrub/ bushes $(29.99 \%)$, plantation $(22.79 \%)$, rice field (19.74\%), settlements (10.48\%), forest $(9.77 \%)$, and water body $(9.70 \%)$.

Acknowledgments: (i) Ministry of Research, Technology and Higher Education of the Republic of Indonesia; (ii) State Polytechnic of Sriwijaya.

\section{References}

1. Indrayani., E. Buchari, D. D. A. Putranto, E. Saleh, Analysis of land use in the Banyuasin district using the image Landsat 8 by NDVI method. AIP Conference Proceedings 1903, 030007, https://doi.org/10.1063/1.5011514 (2017)

2. Bappeda Kabupaten Banyuasin, 2016, Peta Rencana Pola Ruang Kabupaten Banyuasin Tahun 2012-2032. http://simbangda.banyuasinkab.go.id, Badan Perencanaan Pembangunan Daerah dan Penelitian Pengembangan Kabupaten Banyuasin (2016)

3. Departemen Pekerjaan Umum, Tata Cara Perencanaan Geometrik Jalan Antar Kota. Direktorat Jenderal Bina Marga, Jakarta (1997)

4. T. M. Lillesand, R. W. Kiefer, Remote Sensing and Image Interpretation, 6th Edition. Jhon Wiley \& Sons Inc, New York (2008)

5. Adisasmita dan S. Adji, Transportasi dan Pengembangan Wilayah. Edisi Pertama, Graha Ilmu, Yogyakarta (2011)

6. S. Ritohardoyo, Penggunaan dan Tata Guna Lahan. Ombak, Yogyakarta (2013)

7. W. R. Cotton, R. A. Pielke, Human Impacts on Weather and Climate. Second Edition, Cambridge (2007)

8. H. Subagyo, Karakteristik dan Pengelolaan Lahan Rawa. Balai Besar Penelitian dan Pengembangan Sumberdaya Lahan Pertanian, Badan Penelitian dan Pengembangan Pertanian, Departemen Pertanian, Bogor (2006)

9. T. Alihamsyah, E. E. Ananto, H. Supriadi, I. G. Ismail, D. E. Sianturi, Dwi Windu Penelitian Pertanian Lahan Rawa: Mendukung Pertanian Masa Depan. Pusat Penelitian dan Pengembangan Tanaman Pangan, Bogor (2000) 
10. Saaty, T.L. Decision Making with the Analytic Hierarchy Process. Int. J. Services Sciences, Vol. 1, No.1: 83- 98, www.colorado.edu/geography/geog-5113 (2008)

11. Tao, J., Chen, H., Xiao, D. Influences of the Natural Environment on Traditional Settlement Patterns: A Case Study of Hakka Traditional Settlements in Eastern Guangdong Province. Journal of Asian Architecture and Building Engineering, 9 - 14, https://www.jstage.jst. go.jp/article/jaabe/16/1/16_9/_pdf (2017)

12. Putro dan Nurhamsyah. Pola Permukiman Tepian Air (Studi Kasus : Desa Sepuk Laut, Punggur Besar dan Tanjung Saleh Kecamatan Sungai Kakap, Kabupaten Kubu Raya. Jurnal Langkau Betang, Vol. 2, No.1: 65-76, file:///C:/Users/Pavillion/ Downloads/13841-42111-1-SM\%20.pdf (2016)

13. Ali Wjaya dan S. Cahyono, Analisis Perubahan Penggunaan Lahan di Kota Pekalongan Tahun 2003, 2009, dan 2016. Jurnal Teknik ITS, Vol. 6, No.2:C417C420, file://C:/Users/Pavillion/Download/24454-57215-1-PB.pdf (2017)

14. Undang-undang Republik Indonesia No. 18 Tahun 2013, Pencegahan dan Pemberantasan Perusakan Hutan (2013)

15. T. Subramani, dan S.L. Nanda, National Highway Alignment Using GIS. International Journal of Engineering Research and Applications (IJERA), Vol. 2, Issue 4, JulyAugust: 427 - 436, www.ijeia.com/papers/ vol2_issue (2009) 